\title{
Job Satisfaction and Absenteeism on the Performance of Lecturer in Private Higher Education in Semarang
}

\author{
Arnis Budi Susanto ${ }^{1 *}$, Suyatno $^{2}$ and Theresia Susetyarsi ${ }^{3}$ \\ ${ }^{1}$ University of Jember, Kalimantan No. 37, 68121 Jember, Indonesia \\ ${ }^{2}$ STIE AKA Semarang, Citarum No. 44, 50122, Semarang, Indonesia \\ ${ }^{3}$ STIE Semarang, Menoreh Utara Raya No. 11 50236, Semarang, Indonesia
}

\begin{abstract}
Objective - The lecturer is a key element in higher education. This study aims to examine the relationship of job satisfaction lecturer on the performance of lecturer in private higher education in Semarang. Framework constructs in this study presents a variable relationship to one another, illustrating both individual performance and job satisfaction awoke from elements of soft and hard approach.

Methodology/Technique - The sample of this research was determined by using two stage random sampling of 200 lecturers at private higher education in Semarang. Data were analyzed with structural equation modeling (SEM).

Findings - The empirical results showed that job satisfaction is able to reduce absenteeism and improve the performance of lecturer in private higher education, both directly and indirectly.

Novelty - This research findings supported by original data.

Type of Paper: Empirical.
\end{abstract}

Keywords: Job Satisfaction; Absenteeism; Job performance, Semerang.

JEL Classification: I23, J21.

\section{Introduction}

The issue of employee absenteeism has long been a focus of research in the field of human resource management. This is caused by the employee's performance is affected by factors of job satisfaction is able to reduce absenteeism (Becker, 2008). The same is happening in the private higher education, where the lecturer as key elements in the private higher education are required to have a good performance and meet its obligations, known as Tridharma which include education, research, and community service.

The regulations set the responsibility and obligations of lecturers, but only a few lecturer at private higher education still had a poor performance expected or meet the criteria. For lecturers who have the certification course has an obligation to comply, the concern is for lecturers who do not have the certification still has not done so Tridharma showed unsatisfactory performance.

The cause of absenteeism lecturer in meeting these obligations can be triggered by various causes.

\footnotetext{
* Paper Info: Received: October 26, 2016

Accepted: April 6, 2017

* Corresponding author:

E-mail: arnis.fe@unej.ac.id

Affiliation: University of Jember, Indonesia.
} 
Relationships between individuals that affect job satisfaction may be the cause of the absenteeism impact on private higher education performance as proposed by Herberg (1959). Aside from individual factors, Tyson and York (2000) suggests another cause of the hard approach such as policy that affect employee performance.

On the basis of the background and some of the theory study, it can be said that the lecturer as one of the important resources that are key to success in achieving the work of private colleges must have a good level of job satisfaction. To achieve this, the private universities need to know the motivation factor that can improve job satisfaction which in turn can reduce the absenteeism.

This study examines the relationship between job satisfaction and performance of lecturers in Private Higher Education in Semarang.

\section{Literature Review}

\subsection{Job Satisfaction}

The model developed by Christen (2006), is a model of analysis of the relationship of work to examine the relationship between job satisfaction and variable-influential variable or determinant variables, such as individual performance and effort (work effort). The study uses the theoretical basis of agency (agency theory) that examined the impact of work on job satisfaction efforts, and how the work effort they affect the relationship between job satisfaction and individual performance.

Furthermore, this study explains that in theory, organizational psychology, intrinsic and extrinsic factors are a determinant variable on employee job satisfaction (Manisera 2005). It was explained that a regular income such as salary, has a significant positive effect on job satisfaction, but not to the work effort. While the extra income (profit sharing) as bonus and other compensation showed significant positive effects, both on the work effort or job satisfaction (McCaausland 2002).

\subsection{Job Performance}

Christen, 2006, concluded that the performance of individuals, in this case the manager of a retail establishment, it is significantly influenced by work effort (effort), which was born from the commitment of the manager's job. Further stated that the elements of work efforts and significant positive effect on job satisfaction of managers. Research on the commitment and job satisfaction is a topic that is still very interesting to study at this time, because the problem of job satisfaction will continue to appear in various organizations and companies, as well as still found differences between some of the results of previous studies. According Restuningdiah 2009, the research results show that, there is a positive relationship between work effort and job satisfaction. Meyer, 1990, to examine the relationship between performance with affective commitment (affective commitment) that emotional involvement with the organization and ongoing commitment (continuance commitment), namely the introduction of employee costs in relation to employee discharge rate (turnover). He found that affective commitment is positively related to performance, while continuing a commitment negatively related to performance measurement.

So the work effort is one element of the job factor, which is strongly influenced by motivation, perceptions of employment (job perception) and other management elements (Christen 2006). The motivation in this case is the desire to do something as a willingness to expend a high level of effort for the organization's goals (Robbins 2002). Motivation is important to improve the morale of employees so that they can give birth to a commitment desired by the organization and eventually gave birth to job satisfaction. The relationship between motivation, morale and optimal results have a linear relationship in the sense that, with the provision of a good motivation, the passion of employees will be increased and the work will be optimized in accordance with the standards of performance expected.

Job satisfaction (job satisfaction) is an emotional state employees were to happen, or not happen through the meeting point between the remuneration of employees and the company or organization to the level of the value of fringe benefits that are desired by the employee (Martoyo 2000). Job satisfaction spawned an 
emotional attitude of fun and make someone loves his job (Moynihan 2000). This attitude is reflected by the morale, discipline, and job performance, which in turn positively affects the overall performance. Therefore, job satisfaction has a great significance, both for the employees and the company, primarily to create a positive situation in the company's work environment

\subsection{Conceptual Framework}

The conceptual Framework in this research presents a variable relationship to one another that describes both the performance of the profession (people), as well as job satisfaction, awakened from the elements of HRM approach, through soft and hard approach. Further illustrated that both individual performance and job satisfaction has a positive correlation with the performance of the company / organization as showed Figure 1.

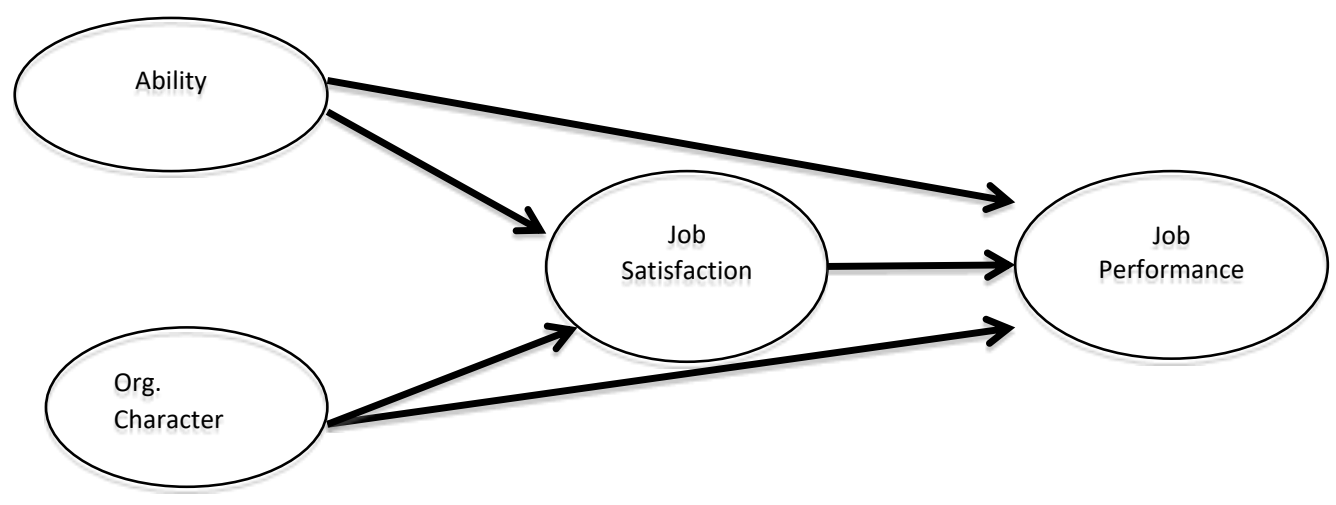

Figure 1. Conceptual Framework

Working ability (ability) in this case awakened from elements of competencies possessed by lecturer through skills (skills) and work experience

Characteristics of the organization, made up of external and internal character code that is owned by a company, both of which provide an enormous influence on employee job satisfaction (R. Gibbons 1998), states that the external characteristics of the organization consists of several elements, among which are; innovation and courage (innovation and risk taking) face various challenges organizations. While Christen, (2006), indicates the character's internal organization consisting of several elements among them; fixed income as salary, labor relations, working facilities and supervision of the leadership.

\subsection{Hypothesis}

Based on the background of the problem, conceptual framework, the study hypothesis is proposed to follow:

1. Hypothesis direct effect of exogenous variable $\mathrm{X} 1, \mathrm{X} 2$ of the endogenous variable $\mathrm{Y} 1 \mathrm{Job}$ Satisfaction

2. $\mathrm{H}_{\mathrm{a} a}$ : There is a positive and significant direct effect on the Ability

3. $\mathrm{H}_{1 \mathrm{~b}}$ : There is a positive and significant direct effect on the Organizational Character

4. Hypothesis direct effect of exogenous variable $\mathrm{X} 1, \mathrm{X} 2, \mathrm{Y} 1$ of the endogenous variable $\mathrm{Y} 2$ job Performance

5. $\mathrm{H}_{2 \mathrm{a}}$ : There is a positive and significant direct effect on Ability

6. $\mathrm{H}_{2 \mathrm{~b}}$ : There is a positive and significant direct effect on Organization Character

7. $\mathrm{H}_{2 \mathrm{C}}$ : There is a positive and significant direct effect on Job Satisfaction

8. Hypothesis indirect effect of exogenous variable $\mathrm{X} 1, \mathrm{X} 2$, of the endogenous variable $\mathrm{Y} 2$ job Performance

9. $\mathrm{H}_{3 \mathrm{a}}$ : There is a positive and significant direct effect on Ability 
10. $\mathrm{H}_{3 \mathrm{~b}}$ : There is a positive and significant direct effect of Organization Character

\section{Methodology}

This research is a quantitative explanatory that examine the relationship and position of the variables in the study. The data used are primary data obtained from questionnaires to respondents. As for the time of the study, done for 6 months i.e. from February 2016 until August 2016.

\subsection{Population and Sample}

The population in this study includes lecturers at private higher education in Semarang, Central Java. The sample using Random is sampling. The sample total in this research is 200 lecturers private higher education in Semarang. Central Java

\subsection{Data Analysis}

Data obtained from questionnaires and using a Likert scale of measurement. Once indicators specified research and measurement techniques, statistical used is a descriptive analysis to explain the relationship between the study variables. It is also used questionnaire results obtained using SEM (structural equation model). This analysis also allows to perform three activities simultaneously, namely, the examination of the validity and reliability of the instrument (equivalent to confirmatory analysis), the test model of the relationship between the latent variables (similar to the analysis path), as well as get a useful model to estimate (Ferdinand 2000).

\section{Results}

Based on a conceptual framework that used in this research, then we tested toward the hypothesis by testing in structural equation models. The test result is presented in table 1 below.

Table 1. Hypothesis Testing

\begin{tabular}{|c|c|c|c|c|c|c|}
\hline \multirow[b]{2}{*}{ HIP } & \multirow[b]{2}{*}{ Independent Variable } & \multirow[b]{2}{*}{ Dependent Variable } & \multicolumn{4}{|l|}{ Direct Effect } \\
\hline & & & Standardize & CR & p-value & Information \\
\hline H1a & Ability & Job Satisfaction & 0.216 & 2.010 & 0.043 & Significant \\
\hline H1b & Organization Character & Job Satisfaction & 0.401 & 2.342 & 0.019 & Significant \\
\hline $\mathrm{H} 2 \mathrm{a}$ & Ability & Job Performance & 0.404 & 2.978 & 0.003 & Significant \\
\hline $\mathrm{H} 2 \mathrm{~b}$ & Organization Character & Job Performance & 0.204 & 2.136 & 0.033 & Significant \\
\hline $\mathrm{H} 2 \mathrm{c}$ & Job Satisfaction & Job Performance & 0.138 & 2.061 & 0.038 & Significant \\
\hline \multicolumn{7}{|c|}{ Indirect Effect } \\
\hline \multicolumn{2}{|c|}{ Variable Independent } & Variable Depend & $\begin{array}{l}\text { Variable } \\
\text { Intervening }\end{array}$ & \multicolumn{2}{|c|}{ Standardize } & Information \\
\hline \multicolumn{2}{|c|}{ H3a Ability } & Job Satisfaction & Job Performance & \multicolumn{2}{|c|}{0.208} & Significant \\
\hline \multicolumn{2}{|c|}{ H3b Organization Character } & Job Satisfaction & Job Performance & \multicolumn{2}{|c|}{0.124} & Significant \\
\hline
\end{tabular}

\section{Discussion}

\subsection{Effect of Ability, Organization Character to Job Satisfaction}

This result explains that the ability that you have will affect the level of faculty satisfaction. as well as the character of the existing organizations will also affect satisfaction. Lecturers have already gotten job 
satisfaction it can increase their motivation for doing his job as a lecturer including carrying Tridharma of higher education.

\subsection{Effect of Ability, Organization Character, job satisfaction to Job Performance}

The better the ability and character of the organization as well as job satisfaction obtained lecturer will improve brand performance. This result explains hypothesis testing in this study suggest that there is a positive influence ability, character of the organization and job satisfaction on the performance of lecturers in private higher education.

\subsection{Indirect Effect Ability, Organizational Character to Job Performance}

The findings in this study explain that the ability and character of the organization will improve performance through job satisfaction. This result explains that the ability and the characteristics that will improve job satisfaction which the lecturer has achieved what was expected by the lecturer with good motivation from ourselves and from outside in this case the private higher education. The private higher education also has approached both hard and soft. the achievement of satisfaction of the faculty will be more motivated in doing their job and will reduce absenteeism their conversely, if the organization did not pay attention to job satisfaction it will bring defaulters tendency for lecturer in performing their duties so the impact on performance.

\section{Conclusion}

From The study we can conclude that, Ability, Organization Character, has a positive effect on Job Satisfaction. Ability, Organization character, and job satisfaction also have a positive effect on job performance. There is a positive effect and a significant relationship ability, organization's character on job performance through job satisfaction.

These results indicate that the variables in this study had a positive influence. where the ability and character of the organization will increase job satisfaction and performance of lecturers. This result can be explained also that the better job satisfaction and will reduce absenteeism so the impact on the performance of lecturers. Therefore, private higher education in Semarang should consider both soft and hard approaches to reduce absenteeism.

\section{References}

Andraeni N.N.N. (2005), Effect of Work Stress Work Motivation and Employee Performance PT. H.M. Sampoerna Tbk. Surabaya, Thesis, Natural Resources Development Studies Graduate Program Airlangga University, Unpublished.

Bartel, A. P. (2004). Human resource management and organizational performance: Evidence from retail banking. ILR Review, 57(2), 181-203.

Becker S. G., and de Oliveira M.L.C., (2008), Study on the Absenteeism of Nursing Professionals in a Psychiatric Centre in manaus, Brazil, Rev Latino-am Enfermagem, janeiro fevereiro; 16(1), 109-14

Cook A.L., (2008), Job Satisfaction and Job Performance: Is the Relationship Spurious, Thesis, Graduate Study, Texas A \& M University.

Cristen M., Iyer G., Soberman D., (2006), Job Satisfaction, Job Performance and Effort; A Reexamination Using Agency Theory, Jounal of Marketing, 70, 137-150

Ferdinand A., (2000), Structural Equation Modelling in Management Research; Application in the Elaborate Models for Thesis and Dissertation Research Agency Undip Publishers, Semarang.

Heller, D., Judge, T. A., \& Watson, D. (2002). The confounding role of personality and trait affectivity in the relationship between job and life satisfaction. Journal of Organizational Behavior, 23(7), 815-835.

Huselid, M. A. (1995). The impact of human resource management practices on turnover, productivity, and corporate financial performance. Academy of management journal, 38(3), 635-672. 
Judge, T. A., Locke, E. A., \& Durham, C. C. (1997). The dispositional causes of job satisfaction: A core evaluations approach. Research In Organizational Behavior, 19, 151-188.

Katou, A. A. (2008). Measuring the impact of HRM on organizational performance. Journal of Industrial Engineering and Management, 1(2), 119-142.

Kearney C. A., (2008). An Interdiciplinary Model of School Absenteeism in Youth to Inform Professional Practice and Public Policy, Educ Psychol Rev, DOI 10.1007/s10648-008-9078-3

Manisera M., Dusseldorp E., Kooij A.J., (2005). Component Structure of Job Satisfaction Based on Herzberg's Theory, Department of Quantitative Methods. University of Brescia, Italy.

McCausland W. D., Pouliakas K., and Theodossiou I., 2002, Some are punished and some are rewarded: A study of the impact of performance pay on job satisfaction, Centre for European Labour Market Research. University of Aberdeen Business School, Aberdeen, Scotland, UK.

Allen, N. J., \& Meyer, J. P. (1990). The measurement and antecedents of affective, continuance and normative commitment to the organization. Journal of occupational and organizational psychology, 63(1), 1-18.

Mikalachki A. and Gandz J., (2012). Measuring Absenteeism, Erudit. Journal of Industrial Relations, 34(3), 516-545.

Saari, L. M., \& Judge, T. A. (2004). Employee attitudes and job satisfaction. Human resource management, 43(4), 395407.

Seniati L., (2006), Influence Work Period, Personality Trait, Job Satisfaction and Psychological Climate Commitment Against Lecturer at the University of Indonesia, Makara: Social Humanities, 10(2), 88-97.

Watson, L. M. (2009). Leadership's influence on job satisfaction. Radiologic technology, 80(4), 297-308.

Worrell, T. G. (2004). School psychologists' job satisfaction: Ten years later (Doctoral dissertation, Virginia Tech). 